\title{
Kepemimpinan Kontingensi Kiai Dalam Memanajerial Pondok Pesantren Al- Ittihad Lembung Timur Lenteng Sumenep
}

\author{
Ali Rahmat ${ }^{1}$, Fika Fitrotin Karomah ${ }^{2}$ \\ ${ }^{1}$ STIT Al-Karimiyyah Sumenep, ${ }^{2}$ STAI Miftahul Ulum Tetate Sumenep \\ ali_rahmat65@yahoo.com
}

\begin{abstract}
The results of this research showed that the community's views on kiai's leadership turned out to provide positive responses and meanings. This is certainly influenced by the skills of the kiai in managing Pondok Pesantren Al-Ittihad, caring about the interests of the community, and their participation in social society. The kiai's leadership practice appear in the clear and structured division of tasks, tolerance and full trust. So that boarding school (pesantren) officials like the leadership style of kiai because kiai are also very skilled in applying different leadership models according to situations and conditions. The factors that influence Kiai's leadership include environmental factors, educational background, and experience factors.
\end{abstract}

Keywords: Contingency Leadership, Kiai, Pondok Pesantren

\begin{abstract}
Abstrak
Hasil penelitian ini menunjukkan bahwa pandangan masyarakat terhadap kepemimpinan kiai ternyata memberikan respon dan makna positif. Hal demikian tentu dipengaruhi oleh keterampilan kiai dalam mengelola pondok pesantren $\mathrm{Al}$ Ittihad, sikap peduli terhadap kepentingan masyarakat, dan partisipasinya terhadap sosial kemasyarakatan. Praktik kepemimpinan kiai tampak dalam pembagian tugas yang jelas dan terstruktur, sikap toleransi dan memberikan kepercayaan penuh sehingga pengurus pesantren menyukai gaya kepemimpinan kiai karena kiai juga sangat terampil dalam menerapkan model kepemimpinan yang berbeda sesuai situasi dan kondisi. Adapun faktor-faktor yang mempengaruhi kepemimpinan kiai di antaranya adalah faktor lingkungan, latar belakang pendidikan, dan faktor pengalaman
\end{abstract}

Kata Kunci: Kepemimpinan Kontingensi, Kiai, Pondok Pesantren

\section{Pendahuluan}

Kepemimpinan merupakan suatu proses di mana pimpinan dilukiskan akan memberikan perintah atau pengaruh, bimbingan, atau proses mempengaruhi pekerjaan orang lain dalam memilih dan mencapai tujuan yang telah ditetapkan. Mengingat hal itu manusia terlahir ke bumi memiliki tugas untuk menggali potensi kepemimpinannya dalam rangka memberikan pelayanan 
serta pengabdian yang diniatkan semata-mata karena amanat Allah SWT, yaitu dengan cara memainkan perannya sebagai pembawa rahmat bagi alam semesta (rahmatan lil alamin).

Untuk itulah Rasullah SAW diutus untuk menyempurnakan akhlak manusia. Untuk mempertegas penciptaan Manusia, Rasullah SAW bersabda:

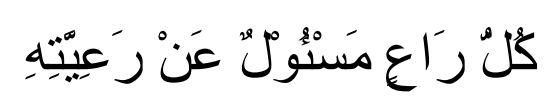

Artinya: "Setiap orang adalah pemimpin dan kelak akan dimintakan pertanggung jawabannya berkaitan dengan kepemimpinannya". ${ }^{\text {I }}$

Hadis ini menjelaskan bahwa manusia telah terlahir ke bumi sebagai pemimpin dan tugas manusia harus menghidupkan nilai kepemimpinannya. Jadi, kepemimpinan adalah potensi yang ada pada diri manusia, tergantung dari cara manusia itu sendiri untuk menentukan dirinya sebagai pemimpin dalam kehidupannya.

Dahulu banyak orang yang beranggapan bahwa kepemimpinan itu tidak dapat dipelajari. Sebab kepemimpinan adalah suatu bakat yang diperoleh seseorang sebagai suatu kemampuan istimewa yang dibawa sejak lahir. Jadi, orang menyatakan bahwa memang tidak ada dan diperlukan teori dan ilmu kepemimpinan. Suksesnya kepemimpinan itu disebabkan oleh keberuntungan seorang pemimpin yang memiliki bakat yang luar biasa, sehingga dia memiliki kharisma dan kewibawaan untuk memimpin massa yang ada disekitarnya. ${ }^{2}$

Pada perkembangan selanjutnya, kepemimpinan tidak lagi didasarkan pada bakat dan pengalaman saja, akan tetapi pada penyiapan secara terencana, penyelidikan, dan percobaan untuk membangkitkan sifat-sifat pemimpin yang optimal agar berhasil dalam mencapai tugas-tugasnya. Nilai kepemimpinan itu tidak lagi ditentukan oleh bakat alam, akan tetapi dapat ditentukan oleh kemampuan dalam menggerakkan banyak orang untuk melakukan satu karya bersama. Berkat pengaruh kepemimpinan yang diperoleh melalui pelatihan dan pendidikan.

Hasil penelitian awal yang dapat peneliti sajikan pada penelitian ini terdapat pada pelaksanaan agenda rapat evaluasi seluruh lembaga pendidikan Islam yang ada di bawah naungan yayasan Al-Ittihad yang diselenggarakan setiap tiga bulan sekali. Dalam rapat itu sempat memperbincangkan masalah seragam putri bagi siswi yang menempuh pendidikan formal di sana. Pada musyawarah tersebut juga ada pendapat sebagian guru yang mengusulkan untuk memberikan instruksi pemakaian rok, sementara sebagian yang lain mengistruksikan untuk memakai celana. Perbedaan pendapat tersebut memiliki alasan-alasan yang sama-sama kuat sesuai argument masing-masing.

Pada kesempatan itu dewan guru meminta kiai untuk memberikan masukan ide-ide cemerlang yang dapat dijadikan pedoman dalam pengambilan keputusan. Ternyata Kiai hanya

\footnotetext{
${ }^{1}$ Jalaluddin Abdurrahman As-Sayuthi, Al-jami’u As-Soghir Fii Ahaadiisti Al-basyiri An-nadziri ( Mesir: Syarikat Maktabah Wa Matba'ah Mustofal Baa Bii Al-Halubi, TT), 93.

${ }^{2}$ Kartini Kartono. Pemimpin dan Kepemimpinan (Jakarta: PT Rajagrafindo Persada, 2006), 55. Indonesian Journal of Islamic Education Studies (IJIES) Volume 2, Nomor 2, Desember 2019 
menyatakan "saya lebih memilih jalan tengah saja, yang tepenting bagi saya pakaian itu menutupi aurat bukan membungkus aurat. Yang terpenting pula tidak mengurangi nilai budaya pesantren." Kemudian keputusan akhir siswi diputuskan memakai rok.

Pada agenda rapat kedua membicarakan tentang masalah kopiah bagi para guru. Dalam tradisi pesantren kopiah menjadi simbol dan identitas moral bagi para santri. Maka layaklah seorang yang menempuh pendidikan ataupun mengajar di lembaga pendidikan Pesantren memakai kopiah. Namun yang terjadi perbincangan terkait kopiah tersebut ada pihak yang menyetujui dan ada yang tidak sama sekali. Hal tersebut menjadi perbincangan yang memakan waktu yang cukup lama untuk diambil suatu keputusan, karena masing-masing pihak memiliki alasan yang sama-sama kuat.

Dewan guru meminta pertimbangan dan masukan ide untuk dijadikan keputusan terakhir kepada kiai yang sekiranya semua pihak merasa puas atas keputusan yang ditetapkan oleh kiai. Namun yang terjadi kiai hanya memberikan pernyataan bahwa jika sekiranya tidak memberatkan dan tidak mengganggu efektifitas proses KBM, memakai kopiah. Demikian pula sebaliknya. ${ }^{3}$

Hal tersebut menunjukkan bahwa kiai lebih mengedepankan atas pemahaman terhadap latar belakang sosial yang dimiliki oleh masing-masing guru. Karena di sana para guru banyak pendatang dari luar kota. Dan mereka didasari atas latar belakang pendidikan yang berbeda-beda. Ada yang berasal dari pesantren, dan ada pula yang berasal dari luar pesantren. Sehingga merasa asing bagi mereka untuk memakai kopiah bagi guru yang berasal dari pendidikan luar pesantren. Keputusan akhir dari permasalahan tersebut menghasilkan keputusan yang juga bersifat moderat dan memberikan kebebasan yakni ada sebagian guru memakai kopiah sebagian yang lain tidak memakai kopiah dan berlaku hingga sekarang.

\section{Metode Penelitian}

Pendekatan yang digunakan oleh peneliti dalam penelitian ini adalah pendekatan kualitatif. Data yang dikumpulkan dalam penelitian ini berupa kata-kata tertulis atau lisan dari orang dan perilaku yang dapat diamati. ${ }^{4}$ Untuk itu peneliti bertindak sebagai instrumen sekaligus pengumpul data yang berlangsung di Pondok Pesantren Al-Ittihad Lembung Timur Lenteng Sumenep dengan melakukan wawancara dan observasi sebagai teknik pengumpulan data. Kemudian data dianalisis sesuai dengan fokus penelitian.

\footnotetext{
${ }^{3}$ Ahmad, Interview, Lembung Timur.

${ }^{4}$ Lexy J. Moleong, Metodologi Penelitian Kualitatif ( Bandung: PT Remaja Rosdakarya, 2005), 4. 


\section{Praktik Kepemimpinan Kiai di Pondok Pesantren Al-Ittihad Lembung Timur Lenteng}

\section{Sumenep}

Masyarakat memiliki kecenderungan dan pandangan yang positif terhadap kepemimpinan kiai di Pondok Pesantren Al-Ittihad. Walaupun masyarakat mengutarakan pendapat yang berbeda-beda, tetapi tidak mengurangi esensi sikap kecintaan masyarakat terhadap pola kepemimpinan kiai di pesantren. Hal ini dapat kita lihat dari pengorbanan tenaga dan materi yang diberikan oleh masyarakat untuk kepentingan pesantren utamanya kepada kiai. Bagi masyarakat lembaga pendidikan Islam baik madrasah, sekolah atau pondok pesantren dijadikan sebagai media pencerahan nilai-nilai agama, dan benteng pertahanan nilai-nilai dan budaya Islam.

Selain menduduki jabatan sebagai pengasuh pesantren, kiai juga diminta oleh masyarakat untuk memimpin, mengkordininasi, memberikan pendidikan, mengarahkan, dan memecahkan masalah yang ada dalam lingkup sosial masyarakat tersebut.

Adapun partisipasi masyarakat terhadap pesantren tidak hanya pada sektor pendidikan saja, akan tetapi pada sektor pembangunan lembaga pendidikan pesantren. Bahkan ada sebagian masyarakat yang berani menghibahkan sebidang tanah untuk perluasan pesantren dan pembangunan yang terkait dengan pesantren. Hal ini menunjukkan bahwa pola kepemimpinan kiai di pesantren disukai dan mendapat respon positif serta dukungan besar dari masyarakat. Ini terjadi karena kiai mampu memenuhi kebutuhan masyarakat akan bimbingan ilmu keagamaan sehingga masyarakat merasa berterima kasih atas bimbingan dan pendidikan yang telah diberikan oleh kiai untuk masyarakat.

Interaksi antara kiai dengan masyarakat terjalin dengan baik, ini tidak lain hanya bertujuan agar pesantren mampu memberikan pelayanan bimbingan keagamaan dan pendidikan, mampu memenuhi tuntutan zaman, serta mampu mengkritisi zaman bagi masyarakat khususnya kalangan anak muda. Dalam kelompok masyarakat, orang-orang yang dapat mempengaruhi tersebut biasanya disebut sebagai tokoh masyarakat atau pemuka masyarakat. Mereka dianggap sebagai tokoh masyarakat itu tentu tidak lepas dari penilaian anggota kelompok yang hidup dalam lingkungannya. Dari waktu ke waktu penilaian itu sekaligus berfungsi sebagai alat untuk mengukur seberapa jauh pengaruh dari masing-masing tokoh tersebut, baik dari sudut kemampuan manajerial maupun dari sudut intelektual.

Kemampuan manajerial akan terlihat melalui interaksi tokoh dengan masyarakat yang dipimpinnya seperti menggerakkan anggota masyarakat untuk berdiskusi dalam memecahkan masalah tertentu. Kepemimpinan dalam masyarakat pada waktunya akan membentuk kelompokkelompok dinamis yang bercorak pikir berbeda-beda. Kepemimpinan dalam masyarakat sesungguhnya merupakan pencerminan dari kehendak masyarakat yang bebas dan merdeka, karena dia lahir dari, oleh, dan untuk masyarakat itu sendiri. ${ }^{5}$

\footnotetext{
${ }^{5}$ Khatib Pahlawan Kayo, Kepemimpinan Islam \& Dakwah (Jakarta: AMZAH, 2005), 21. Indonesian Journal of Islamic Education Studies (IJIES)

Volume 2, Nomor 2, Desember 2019 
Dalam realitas hubungan sosial, pesantren senantiasa menjadi kekuatan yang amat penting yaitu sebagai pilar sosial yang berbasis nilai keagamaan. Nilai keagamaan ini menjadi basis kedekatan pesantren dengan masyarakat. Hal ini bisa terjadi karena pesantren lahir dari harapan dan cita-cita masyarakat yang rindu akan tatanan kehidupan sosial berbasis nilai keagamaan. ${ }^{6}$

Jadi, dari uraian tersebut dapat diketahui bahwa kepemimpinan kiai di pesantren sangat dikagumi dan disukai oleh segenap masyarakat. Karena melihat dari sosok kepribadiannya dan nilai partisipasi Kiai pada kegiatan sosial kemasyarakatan yang amat tinggi beliau pertahankan. Kiai memiliki keterampilan dan gagasan yang baik dalam memecahkan masalah yang ada di masyarakat untuk dicarikan solusi yang cepat dan tepat dari suatu persoalan yang dihadapi masyarakat seperti halnya membina persatuan dan kesatuan umat agar hidup rukun dan damai, perbaikan dalam bidang pendidikan. Sehingga hal ini menimbulkan sikap prihatin dan antusias masyarakat terhadap kepemimpinan kiai di pesantren maupun di masyarakat.

Perilaku kepemimpinan kiai di Pondok Pesantren Al-Ittihad menimbulkan beberapa pandangan dan pendapat yang berbeda yang diutarakan oleh pengurus pesantren dan sebagian santri. Akan tetapi walaupun pendapat yang dikemukakan oleh pengurus dan santri berbeda-beda, namun pendapat tersebut menunjukkan sikap seorang bawahan yang menyukai pola kepemimpinan yang kiai terapkan.

Dalam kepemimpinannya, kiai memberikan tugas-tugas yang jelas dan terstruktur kepada para pengurus dan santri, sehingga memudahkan kiai dalam mengatur kepesantrenan tersebut. Adapun tugas yang diberikan oleh kiai itu berdasarkan kompetensi ataupun tingkat kemampuan yang dimiliki oleh tiap individu. Dalam pembagian tugas pesantren dan lembaga pendidikan yang ada, kiai masih memberikan penawaran terkait tugas kerja kepada para pengurus, sementara ustad yang merasa siap menjalankan tugas tersebut kiai meminta untuk segera konfirmasi kepada kiai. Sehingga tugas yang diemban oleh pengurus dapat dipahami dan mudah dijalankan.

Pada tahap pelaksanaan kepemimpinan, kiai menaruh kepercayaan besar kepada pengurus pesantren ketika menjalani tugas, baik tugas yang ada di internal maupun eksternal pesantren. Selain itu pula, kiai juga mengedepankan nilai-nilai demokrasi melalui musyawarah untuk mufakat dalam rangka merencanakan, mengorganisasi kerja. Di mana musyawarah tersebut diselenggarakan setiap satu bulan dan tiga bulan sekali.

Pada waktu pelaksanaan tugas dan kerja, kiai sering memberikan toleransi terhadap pengurus yang masih belum optimal dalam menjalankan tugas dan kerja. Hal itu dilakukan oleh kiai pada kehidupan sehari-hari dan pada rapat evaluasi ketika masing-masing pengurus menyampaikan hasil kerja pada musyawarah rutinitas. Sedangkan pendekatan yang digunakan oleh kiai dalam kepemimpinannya, kiai menggunakan gaya kepemimpinan yang berbeda-beda

\footnotetext{
${ }^{6}$ Rofiq A, Pemberdayaan Pesantren (Yogyakarta: PT LKIS Pelangi Aksara, 2005), 14. 
sesuai dengan situasi dan kondisi yang berbeda. Adapun gaya kepemimpinan yang digunakan oleh kiai antara lain: gaya kepemimpinan partisipatif, demokratis, dan delegatif.

Gaya kepemimpinan partisipatif ini dilakukan ketika kebijakan ingin diambil masih berdasarkan rumusan bersama. Di mana kiai dalam setiap mau mengambil kebijakan yang strategis yang mau ditetapkan terkait pengelolaan maupun penetapan kebijakan baru di pesantren, kiai mengadakan musyawarah dengan melibatkan semua stakeholder pesantren termasuk pimpinan dari masing-masing satuan pendidikan di bawah naungan yayasan Pondok Pesantren Al-Ittihad. Musyawarah tersebut dikenal dengan nama rapat pimpinan. Adapun hasil keputusan berdasarkan kesepakatan bersama tidak semerta-merta dari keinginan kiai itu sendiri seperti halnya persiapan tahun ajaran baru.

Sementara gaya kepemimpinan demokratis ini tampak ketika kiai mau mengambil suatu kebijakan tidak atas keputusan sendiri, akan tetapi kiai masih mengadakan musyawarah untuk menetapkan hal-hal yang mau ditetapkan dengan para pengurus dan pimpinan tiap satuan pendidikan. Seperti halnya rekrutmen guru dan penetapan tanggal haflatul imtihan. Dalam penetapan tanggal haflatul imtihan saja, kiai sempat bermusyawarah dengan pimpinan lembaga pendidikan dan segenap masyarakat.

Pada waktu musyawarah berlangsung sempat terjadi perbedaan pendapat dari masingmasing anggota musyawarah, sebagian ada yang sepakat haflah diadakan, sementara sebagian yang lain tidak menyetujuinya berdasarkan alasan masing-masing. Namun disadari atau tidak pelaksanaan acara tersebut membutuhkan dana yang banyak. Sumber dana untuk perayaan tersebut selain dari pesantren juga dari wali murid dan segenap masyarakat. Sementara tradisi masyarakat di sekitar lingkungan pesantren, jika ada perayaan di pesantren, maka masyarakat menyumbangkan berbagai sarana untuk mensukseskan acara tersebut.

Berangkat dari hal tersebut menjadi pertimbangan bagi kiai dalam memberikan keputusan dalam musyawarah tersebut. Karena melihat kondisi ekonomi dari masyarakat yang masih kurang stabil. Keberlangsungan hidup masyarakat masih bergantung pada hasil pertanian. Sementara masyarakat pada saat itu sedang krisis ekonomi yang disebabkan oleh panen tembakau laku dengan harga yang murah.

Masyarakat merasa kesulitan untuk menyumbangkan dana pada pelaksanaan haflah tersebut. Dengan melihat kondisi masyarakat yang kurang mendukung dalam hal kondisi ekonomi, maka kiai memberikan keputusan bersama dengan anggota musyawarah bahwa pelaksanaan haflah ditiadakan karena kiai tidak ingin keberadaan pesantren memberikan beban yang berat kepada masyarakat.

Adapun gaya kepemimpian delegatif kiai tampak ketika pendistribusian pekerjaan pada masing-masing pengurus pesantren. Pondok pesantren merupakan lembaga yang dikelola oleh kiai. Konsekuensi logisnya ialah dalam pengelolaan pesantren kiai tidak bekerja sendirian, kiai membutuhkan orang lain untuk membantu pekerjaannya, sehingga kiai tidak murni mengelola 
sendirian untuk mewujudkan tujuan yang telah ditetapkan. sehingga keberadaan pengurus pesantren tidak sekedar formalitas saja, akan tetapi mereka dapat bekerja sendiri sesuai dengan fungsinya.

Manajemen pengelolaan keuangan di Lembaga Pendidikan Islam Al-Ittihad itu ada pada yayasan yang dikenal dengan manajemen satu pintu. Seluruh income pesantren masuk pada bendahara yayasan pondok pesantren Al-Ittihad yang bernama Doni Nurhidayat. Kemudian uang tersebut didistribusikan lagi sesuai dengan kebutuhan pesantren. Setiap triwulan pelaporan keuangan diajukan kepada kiai.

Sementara pada pengkondisian santri, kiai mendelegasikan Abdurrahman sebagai tenaga pendidikan dan keamanan, Aguswandi sebagai pengembangan usaha pesantren, Anwari sebagai sosialisasi kebutuhan masyarakat, Idris sebagai perlengkapan sarana kebutuhan pesantren dan lain-lain.

Selain itu pula banyak dari stakeholder pesantren yang membantu pekerjaan kiai dalam pengelolaan pendidikan di pesantren agar tujuan dari penyelenggaraan pendidikan agama Islam di pesantren dapat terwujudkan. Selain itu pula tipe kepemimpinan yang ada pada jati diri kiai adalah tipe kepemimpinan karismatik. Hal ini dilakukan oleh kiai supaya pengurus mampu melaksanakan tugas dengan baik dan efektif.

Sebuah teori kepemimpinan yang disebut dengan teori alur-sasaran (path-goal theory), dengan fokus interaksi perilaku kepemimpinan dengan karakteristik situasi dalam menentukan efektifitas pemimpin. Terdapat empat perilaku kepemimpinan, yaitu direktif, berorientasi tugas, mendukung, partisipatif, dan dua variabel situasional (karakteristik pribadi bawahan dan tuntutan lingkungan) yang memberikan kontribusi paling kuat bagi efektifitas kerja pemimpin. ${ }^{7}$

Kepemimpinan harus bersifat multi-dimensional serba bisa dan serba terampil, agar ia mampu melibatkan diri dan menyesuaikan diri dengan masyarakat. Hal ini menandakan bahwa kepemimpinan itu terdiri atas tiga elemen dasar, yaitu : pemimpin, pengikut, dan situasi. Maka situasi dianggap elemen paling penting karena memiliki paling banyak variabel dan kemungkinan yang bisa terjadi. ${ }^{8}$ Kepemimpinan didominasi oleh kepribadian pemimpin, kelompok pengikut yang dipimpin, dan situasi. Jadi interaksi antara pemimpin dan situasinya akan membentuk tipe atau gaya kepemimpinan tertentu.

Seorang pemimpin di samping harus mempunyai kemampuan konseptual, beliau juga harus mempunyai kemampuan kemanusiaannya sehingga mampu memimpin sebuah pesantren maupun lembaga pendidikan yang dipimpinnya. Sehingga dengan kompetensi yang dimiliki oleh kiai dapat membawa kemajuan bagi pesantren yang dipimpinnya. Selain itu seorang pemimpin

\footnotetext{
${ }^{7}$ Sudarwan Danim, Kepemimpinan Pendidikan (Bandung, ALFABETA, 2010), 91.

${ }^{8}$ Kartini Kartono, Pemimpin dan Kepemimpinan (Jakarta: PT Rajagrafindo Persada, 2006), 78. 
harus mempunyai kepekaan sosial dalam kepemimpinannya sehingga memudahkan kiai dalam menentukan gaya kepemimpinan yang cocok untuk situasi tertentu.

Kemampuan kiai dalam memanajerial Pondok Pesantren Al-Ittihad dipengaruhi oleh beberapa faktor. Adapun faktor yang mempengaruhi perilaku kepemimpinan kiai ialah :

1. Pendidikan

Pendidikan yang maksudkan di sini adalah pendidikan yang ditempuh kiai baik pendidikan formal maupun nonformal. Pendidikan formal Kiai yang pernah ditempuh ialah di pondok pesantren Al-Nuqoyyah Guluk-guluk Sumenep. Di mana pondok pesantren ini merupakan pesantren terkenal dan ternama di kabupaten Sumenep karena tingkat kemajuan dalam memanajerial pendidikan. Selain itu pula Kiai juga pernah menempuh pendidikan di pondok pesantren Darul Ulum Banyuanyar Pamekasan. Pesantren ini merupakan termasyhur di pulau Madura karena output dari pesantren ini mencetak kader-kader yang baik dalam segi intelektual maupun manajerial pendidikan. Latar belakang pendidikan kiai di dua pesantren tersebut dapat memberikan pengaruh besar terhadap kepemimpinan kiai di pesantren. Apalagi kiai melanjutkan pendidikannya setelah tamat di dua pesantren tersebut di Timur Tengah tepatnya di Makkah al Mukarromah.

2. Pengalaman

Faktor pengalaman kiai baik yang didapat pada sosial keagamaan ataupun pengalaman kiai ketika ada pertemuan dengan teman-teman yang sama-sama mengelola pondok pesantren. Hal ini dapat kita ketahui bahwa kiai selain menjadi pemimpin di pesantren, beliau juga berdakwah keluar pesantren. Hal ini sangat memungkinkan jika kiai kunjungan ke pondok pesantren atau lembaga pendidikan lainnya akan terjadi sharing tentang pengelolaannya, karena kontak kiai dengan teman-temanya kuat. Selain itu pula, dapat didukung dengan pengalaman kiai pada organisasi-organisasi formal sosial keagamaan.

\section{Lingkungan}

Lingkungan yang dimaksudkan di sini adalah lingkungan sosial masyarakat pesantren. Karena di lingkungan pesantren terdapat beberapa kelompok masyarakat yang beragam baik dari segi latar belakang sosial, pendidikan, ekonomi, dan lain-lain. Hal ini dapat membentuk perilaku kepemimpinan kiai yang serba bisa, serba terampil atau situasional ketika memberikan suatu kebijakan, tindakan, dan keputusan. Selain itu pula, lingkungan pertemanan sangat memberikan kontribusi besar terhadap perilaku kepemimpinan kiai di pesantren. Hal demikian senada dengan pernyataan Atiqullah menyebutkan bahwa terdapat beberapa faktor yang dapat mempengaruhi kepemimpinan seperti halnya ialah :

a. Faktor kepribadian kiai berupa sifat yang menjadi visi kepemimpinan dan kepengasuhan di beberapa pesantren sehingga secara heroik menggugah santri untuk melakukan apa saja yang diperintahkan oleh kiai sebagai ketaatan. 
b. Faktor pendidikan kiai baik yang ditempuh pada jalur pendidikan formal, pendidikan nonformal kepesantrenan maupun organisasi kemasyarakatan, sangat mempengaruhi terhadap perilaku kiai dalam memimpin pesantren.

c. Faktor pengalaman para kiai dalam organisasi-organisasi formal sosial-keagamaan sangat mempengaruhi terhadap perilaku dan keberhasilan kepemimpinan.

d. Faktor situasi lingkungan kiai di masyarakat pesantren, mereka meyakini pada pemeliharaan tradisi dan nilai-nilai akhlaqul-karimah di antara komunitas pesantren.

e. Faktor prinsip kontinuitas (prinsiple continuity) masyarakat pesantren, mereka meyakini bahwa program pemberdayaan dan pengembangan sumber daya insani dapat memenuhi kebutuhan pesantren. ${ }^{9}$

\section{Penutup}

Interaksi antara kiai dengan masyarakat terjalin dengan baik, ini tidak lain hanya bertujuan agar pesantren mampu memberikan pelayanan bimbingan keagamaan dan pendidikan yang mampu menjawab tantangan zaman bagi masyarakat khususnya kalangan anak muda. Dalam kepemimpinannya, kiai memberikan tugas-tugas yang jelas dan terstruktur kepada para pengurus dan santri, sehingga memudahkannya dalam mengatur kepesantrenan tersebut karena ada yang membantu beliau.

Kiai menaruh kepercayaan besar kepada pengurus pesantren ketika menjalani tugas, baik tugas yang ada di internal maupun eksternal pesantren. Ciri khas kepemimpinan kontingensi kiai di pesantren Al-Ittihad ialah selalu mengedepankan nilai-nilai demokrasi melalui musyawarah untuk mufakat dalam rangka merencanakan, mengorganisasi kerja.

Terdapat beberapa faktor yang mempengaruhi model kepemimpinan kiai di Pondok Pesantren Al-Ittihad. Faktor ini akan memberikan kontribusi besar dan dijadikan pedoman hidup dalam kepemimpinan yang sedang dijalani oleh kiai. Adapun faktor-faktor yang dapat mempengaruhi pola kepemimpinan kontingensi kiai di pondok pesantren al-ittihad ialah : lingkungan, pendidikan dan pengalaman.

\section{Daftar Rujukan}

A, Rofiq dkk. Pemberdayaan Pesantren. Yogyakarta: Pustaka Pesantren, 2005.

Atiqullah. Manajemen \& Kepemimpinan Pendidikan Islam. Pamekasan: STAIN Pamekasan Press, 2010.

Danim, Sudarwan. Kepemimpinan Pendidikan. Bandung: Alfabeta, 2010.

Kartono, Kartini. Pemimpin dan Kepemimpinan. Jakarta: PT Rajagrafindo Persada, 2006.

${ }^{9}$ Atiqullah, Manajemen \& Kepemimpinan Pendidikan Islam (Pamekasan: STAIN Pamekasan Press, 2010), 115-116. 
Kepemimpinan Kontingensi Kiai..., Ali Rahmat \& Fika Fitrotin Karimah

Kayo, Khatib Pahlawan. Kepemimpinan Islam \& Dakwah. Jakarta: AMZAH, 2005.

Moleong, Lexy J. Metodologi Penelitian Kualitatif. Bandung: PT Remaja Rosdakarya, 2005 .

Sayuthi, Jalaluddin Abdurrahman As. Al-jami'u As-Soghir Fii Ahaadiisti Al-basyiri AnNadziri. Mesir: Syarikat Maktabah Wa Matba'ah Mustofal Baa Bii Al-Halubi, TT. 